\title{
THE RÔLE OF MARAGHA IN THE DEVELOPMENT OF ISLAMIC ASTRONOMY : A SCIENTIFIC REVOLUTION BEFORE THE RENAISSANCE
}

\author{
INTRODUCTION
}

Research conducted in the History of Arabic astronomy, within the last three decades, has brought to light a group of texts, that were hitherto unknown, and which radically altered our conception of the originality and scope of Arabic astronomy. The works of astronomers such as Mu'ayyad al-Dìn al-'Urḍi (d. 1266), Nașir al-Din al-Tuusī (d. 1274), Quṭb al-Din al-Shïrāzi (d. 1311), and Ibn al-Shățir (d. 1375), to name only a few, were barely known in the nineteenth century or in the early part of the present century. Only Túsi was mentioned in nineteenthcentury literature, although his contribution was not even recognized. In 1893, Bernard Carra de Vaux wrote in an appendix (vi), to Paul Tannery's Recherches', in regard to Túsi, that while Arabic astronomy did not hold Ptolemy's work with much regard, it did not on its own have enough « génie » to transform astronomy altogether. Subsequent research has shown that de Vaux, armed with his own prearranged concepts of

1. Paul TANNERY, Recherches sur l'histoire de l'astronomie ancienne, Paris, Gauthier, 1893, p. 337-361. The only text of "Urdi that was known in the early part of this century was the one that he wrote on the instruments which he built at Maragha as the engineer of that observatory. See, e.g. Hugc J. SEEMAN, « Die Instrumente der Sternwarte zu Maragha nach den Mitteilungen von al- Urdī", Sitzungsberichte der PhysikalischMedizinischen Sozietät zu Erlangen, 60, 1928, p. 15-126.

Revue de synthèse : IV ${ }^{e}$ S. Nos 3-4, juil.-déc. 1987 
periodization of science, could not see the originality in what later came to be known as the most original chapter of Tiusi's astronomy, despite the fact that de Vaux had actually taken the trouble to translate it. In this chapter, for example, Túsĩ proved a very ingenious theorem, namely that simple harmonic motion could be obtained as a result of allowing two circles - the radius of one of them being twice the size of that of the other - to move one inside the other with the inner circle moving at twice the angular velocity of the outer one and in the opposite direction. These two circles, which were called by Edward S. Kennedy the « Túsi Couple ${ }^{2}$, were used by most astronomers who came after Țúsi up to and including Copernicus.

An assessment similar to that of de Vaux was offered a few years later when François Nau translated the major astronomical work of Bar Hebraeus ${ }^{3}$, and completely misunderstood the significance of two sections in that work, namely sections 6 of chapters three and four of part I ${ }^{4}$, simply because, he too, was under a frame of mind that did not expect to find anything original in those medieval works, which were in no way comparable to the works of the Renaissance. While de Vaux had concluded that Arabic science could not develop any further than it did simply because of its "faiblesse ", and "mesquinerie ", Nau, on the other hand, had the following to say when evaluating the work of Bar Hebraeus and his Arab colleagues of the thirteenth century :

" Au XII [sic, read XIII, A. D. 1279] siècle, à l'époque où écrivait BarHebraeus, les Arabes s'occupaient d'astronomie depuis près de quatre siècles et notre auteur cite un certain nombre de leurs résultats ; mais ces résultats semblent peu importants ; les auteurs arabes que nous connaissons furent surtout des commentateurs et des astrologues amateurs, on ne les a admirés que faute de connaître les œuvres grecques, leurs modèles. On peut donc considérer le présent Cours d'astronomie comme un résumé des œuvres de Ptolémée (avec quelques adjuncta dus aux Arabes)... "

This general underestimation of the rôle of Arabic astronomy also colored the thinking of J. L. E. Dreyer, who wrote towards the beginning

2. See Edward S. Kennedy, "Late Medieval Planetary Theory ", Isis, 57, 1966, p. 365-378, esp. p. 370.

3. François NAU, Le Livre de l'ascension de l'esprit, Paris, Bouillon, 1899.

4. Ibid. : in these chapters, Bar Hebraeus discussed the contradictions in the Ptolemaic system pertaining to the model of the Moon and the equant of the upper planets. It is true that he did not elaborate his criticism enough, nor did he offer new models as alternatives to the Ptolemaic ones, but he was reporting on the status of these problems as he understood them from the Maragha astronomers. In a forthcoming article, the present author plans to discuss the relationship between these sections in Bar Hebraeus's work and the works of the Maragha astronomers.

5. Ibid., p. xiv. 
of this century. The same prejudices and preconceptions prevented Dreyer from appreciating the real significance of the material that was known to him, despite the fact that he showed a great ingenuity in pulling this material together and in bringing some coherence to ideas that were scattered among various obscure publications ${ }^{6}$.

The model that explained the development of Arabic astronomy and which prevailed until the middle of the present century was essentially that of an astronomy that was only a translation of Greek astronomical works, and, at best, did not go beyond the mere summarizing of Greek works. Therefore one studied this tradition expressly to recapture the Greek texts, which were indeed the object of the admiration that Nau had so clearly expressed. Viewed from this perspective Arabic astronomy was perceived as an intermediary that had translated the Greek works between the ninth and the eleventh century, which had preserved this Greek tradition, in order to pass it on to Europe during the twelfth and thirteenth centuries, when Europe was ready to develop its own medieval science. The assumption then, was that once this tradition was handed over to Europe, Arabic astronomy receded from center stage to pass into oblivion, while the real developments were left to take place in Europe, thus leading to one revolution after another independent of any outside agent.

The prevailing periodization could then be summarized along the following stages : (1) the translation stage, when Greek astronomy passed into Arabic, and that seems to have been understood as just a translation stage ; (2) a stage of additional minor commentaries of a type that Nau called adjuncta to Greek astronomy ; and finally (3) a stage of general decline in Arabic scientific creativity, which must have started sometime during the twelfth century just as Europe was in the process of acquiring the Greek heritage, especially the astronomical and mathematical one, through the translations from Arabic into Latin. From then on, there was no longer any need to pay attention to the Arabic tradition, for Europe was developing science on its own.

This essay will attempt to establish that the prevalent model, which is used to explain the development of Arabic astronomy is essentially ahistorical because it neglects or misunderstands three major facts. (1) It fails to understand the nature of the translation period that took place in stage one. (2) This model totally misrepresents the real developments within the Arabic astronomical tradition itself because it neglects the creative

6. John Louis Emil DREYER. History of the Planetary Systems from Thales to Kepler, Cambridge, 1906 (repr. N. Y., Dover, 1953 as $A$ History of Astronomy from Thales to Kepler). 
productivity that had begun as early as the ninth century, concomitantly with the translation activity, and which continued to develop, as far as astronomy is concerned, until well beyond the fifteenth century. (3) It fails to acknowledge the actual extent of the contact between European and Arabic astronomical works which has only been brought to light by the research of the last three decades or so. Once these facts are recognized and studied, the claim can then be made that we need a new periodization in Arabic astronomy, which could explain in a more coherent manner the historical circumstances of the most important transmission phase that determined the parameters of the contact between European and Arabic astronomy.

\section{TRANSLATION PERIOD}

Although we do not know yet the full significance of the early translation period when Greek scientific works were translated into Arabic due to a lack of studies devoted to such translated works as Euclid's Elements, or Ptolemy's Almagest, we still know enough to assert that this period was by no means a simple transfer of texts from one language into the other. Despite the fact that we know very little about the group of translators who worked during this period, and the conditions under which they worked, we possess enough information about two of them, namely Hunain Ibn Isḥāq (d. 873) and Thäbit Ibn Qurra (d. 901) to assess the kind of work that these translators performed.

In the case of Hunain, he left a treatise in which he described his method of translation, as well as the conditions under which he worked 7 . From that treatise we learn that he sought manuscripts from a wide geographical area that covered the entire ancient Near East. Hunain collated the original Greek texts, i.e. edited them, before he embarked upon translating them. We also know from another source that Hunain would first read the sentence in an original Greek text, and then render it in Arabic in his own words as he saw fit ${ }^{8}$. This implies that he must have had an excellent command of the contents of such texts so well, first to understand them, and then to develop the appropriate technical terms in the target language to translate them. Work such as this could not have been developed by a translator who only commanded two languages. In fact, we also know, from Hunain's biography, that he had

7. See Gotthelf Bergsträsser, « Hunain b. Ishāq, "Über die Syrischen und Arabischen Galenübersetzungen" ", Abhandlungen für die Küde des Morgenlandes, 17, 1925, II, p. 4f, $n^{\circ} 3$.

8. Al-Safadī, Khalil b. AybaK, Al-Ghaith al-musajjam, Cairo, 1305 H., I, p. 46, transl. by Franz Rosenthal, The Classical Heritage in Islam, Berkeley, U. C. Press, 1975, p. 17. 
started his career by studying medicine in Baghdad, that is, before he began translating ${ }^{9}$. If this information is accurate, then we must assume that there was sufficient medical knowledge available at this time, first for Hunain to study medicine in order to appreciate someone like Galen for the translation of whose works be devoted nearly his entire life and second, for there to have been enough technical knowledge in Arabic so that Hunain dit not have to coin new technical terms. Finally, the extant works of Hunain, such as his works on ophthalmology, do indeed support the thesis that translators like Hunain were producing original works at the same time that they were translating.

Similarly, a close study of Thäbit Ibn Qurra's career reveals that he too was producing original works, such as his text on the amicable numbers, the sundials, the crescent visibility, etc., while he was correcting Ishāq Ibn Hunain's translations of Euclid's Elements, and Ptolemy's Almagest.

Scientists active during the same period, who do not seem to have depended on these translation activities, further confirm the character of the creativity that was taking place at this time. The work of someone like al-Khwārizmī (c. 800-847), or Habash al-Hảsib (c. 850), or else the Ma'mün astronomers who produced a new set of astronomical tables correcting and updating the Ptolemaic parameters, definitely bespeak of a very active scientific environment that was yielding new results while the translations from Greek were underway. This claim can be made of scientific fields other than astronomy. Moreover, it should be remembered that this period witnessed the birth of a totally new mathematical discipline, namely Algebra, at the hands of Muhammad b. Músá al-Khwārizmi.

During this translation period therefore, astronomy witnessed as much original creative work, as it did translated work. And if we were to assign a name to this stage of Arabic astronomy we would have to call it a period of innovation, or an upsurge in activities, during which Greek works were rendered in Arabic as they were needed, but by mature scientists who knew what they wanted from the Greek heritage. It should be born in mind that this same Greek heritage was neglected in Greek-speaking Byzantium and would have remained so if it were not resuscitated by those concerned scientists working in ninth-century Baghdad.

For our general periodization paradigm, we have to designate this stage as the background phase for what we will later refer to as a genuine revolution in astronomical activity.

9. See, for example, QIFTĩ, Ta'rikh al-hukamä', ed. by Julius LIPPERT, Leipzig, Dieterich'sche Verlagsbuchhandlung, 1903, p. 174. 


\section{THE MARAGHA SCHOOL REVOLUTION}

In order to understand the results achieved by a group of astronomers who lived after the first half of the thirteenth century, and who are now known as the "Maragha School " ${ }^{10}$, one must review the activities that were initiated sometime during the eleventh century, if not earlier. All of these activities seem to have begun with a factual criticism of Ptolemy's Almagest, in which Arabic-writing astronomers managed to isolate the few parameters that were simply erroneous in the Ptolemaic text. The values for the obliquity of the ecliptic, and the precession of the fixed stars, for example, were the two glaring mistakes that were quickly rectified as early as the ninth century. Similarly, the solar apogee of the sun, which was assumed to have been fixed by Ptolemy, was also found to be tied up to precession and hence had moved by about twelve degrees. But most importantly, this early period also witnessed a critical attack on Ptolemy's methodology, as in the case of determining the length of the solar year by using the Method of Seasons ${ }^{11}$.

To understand the new perceptions that led to the Maragha Revolution, the reader should be reminded that Ptolemy himself had described the movements of the planets, including the Sun and the Moon, as moving on epicyclic spheres which were in turn carried within the thickness of other spheres that he called deferents. In the Almagest, these spheres were represented by circles, and were described as though they were mathematical curves, without any attempt to coordinate their motion with the motion of physical bodies having the same shape. In the Planetary Hypothesis, however, Ptolemy described these spheres as physical bodies, and he made no attempt there as well to match these spheres with the mathematical circles that were supposed to describe the universe in the Almagest.

It was these kinds of considerations that were noted by Arabic-writing astronomers, sometime during the eleventh century, and perhaps earlier, and which led Ibn al-Haytham of Bașra and Egypt (d. c. 1048) and the Persian Abü 'Ubayd al-Jüzjāni (d. c. 1070) to write texts objecting specifically to that feature of Ptolemy's astronomy. According to Ibn alHaytham, one could not assume within a physical universe that there can be a sphere that would move uniformly around an axis, which does not pass through its center. The Ptolemaic equant was therefore in direct vio-

10. The term was first introduced by Victor RoBerTs, « The Planetary Theory of Ibn al-Shätir ", Isis, 57, 1966, p. 210, and was later codified by E. KENNEDY, art. cit. supra n. 2, p. 365.

11. Otto Neugebauer, « Thäbit ben Qurra "On the Solar Year" and "On The Motion of the Eighth Sphere" ", Proceedings of the American Philosophical Society, vol. 106, 1962, p. 264-299. 
lation of this rule, and that implied that the models described with great ingenuity in the Almagest could not be describing the real physical universe, and thus should be abandoned in favor of a better set of models, which could meet that requirement. Ibn al-Haytham reported these results in his seminal work, which became a landmark in medieval Arabic astronomy. He called his book al-Shukük calä Batlamyüs (Dubitationes in Ptolemaeum) ${ }^{12}$, in which he surveyed all the works of Ptolemy, and gathered together what seemed to him to be unforgivable contradictions.

The work of Abü cUbayd, on the other hand, took up one specific problem in Ptolemy's astronomy, and attempted to find an alternative

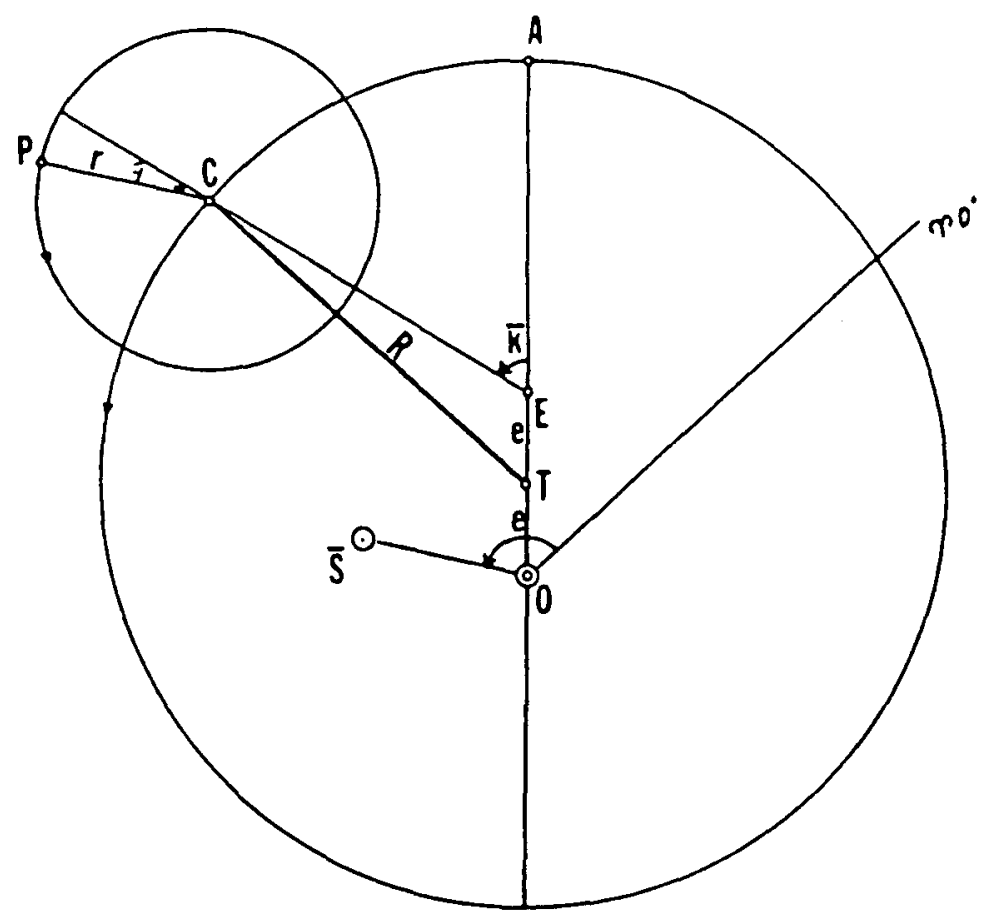

\section{Figure 1}

Ptolemy's model for the superior planets Saturn, Jupiter, and Mars, and for the inferior planet Venus. Point $C$, the center of the epicycle, moves on a deferent with center $T$, but measures equal arcs in equal times around the equant point $E$ instead of the deferent center $T$.

12. See Abd Al-Hamīd Sabra, Nabil Shehaby, Al-Shukūk calä Batlamyüs (Dubitationes in Ptolemaeum), Cairo, National Library Press, 1971. 
solution for it ${ }^{13}$. The problem chosen was the one that was later called the problem of the equant, which was an integral part of Ptolemy's model for the upper planets Saturn, Jupiter and Mars, and the lower planet Venus. In brief, the equant in the model required that a sphere, the deferent sphere, should move at a uniform speed around a point, which was not its center. For a physical sphere, this was an absurdity (see Fig. 1).

With the works of Ibn al-Haytham and Abú cUbayd, the research had begun in earnest, namely on the theoretical level, by objecting to what Ptolemy had postulated, and on the practical level by attempting to offer alternative models to the Ptolemaic ones.

In the following two centuries, the center of these activities shifted to the western part of the Islamic Empire, to Andalusian Spain ${ }^{14}$. The names of al-Bițruji (Alpetragius, c. 1200), Ibn Rushd (Averroes, 1126-1198), and Jābir Ibn Aflah (Geber, c. 1200) have all been mentioned in connection with one reform of Ptolemaic astronomy or another ${ }^{15}$. But the most significant results, from technical and mathematical perspectives were still to be reached in the eastern part of the Empire, and sometime during the thirteenth century and thereafter.

\section{THE THIRTEENTH CENTURY}

If one were to seek a specific century that could be called the Golden Age of Arabic astronomy, one would have to chose the period stretching from the middle of the thirteenth to the middle of the fourteenth. In this century, we know of at least four attempts to resolve the Ptolemaic difficulties, that we have referred to above ${ }^{16}$. The alternative models for the upper planets have been conveniently summarized in one diagram, which was published by Kennedy in $1966^{17}$. The only emendation to be made in that diagram is in the vector connection designated as that of Quṭ al-Din, for there it should be added that that vector connection was originally invented by Mu'ayyad al-Din al-cUrḍi some forty years before Quṭb al-Din (see Fig. 2).

13. George Salıba, «Ibn Sīnā and Abū 'Ubayd al-Jūzjānī : The Problem of the Ptolemaic Equant ", Journal for the History of Arabic Science, 4, 1980, p. 376-404.

14. Léon Gauthier, "Une réforme du système astronomique de Ptolémée ", Journal asiatique, 10 Sér., 14, 1909, p. 483-510.

15. Bernard Goldstein, Al-Bitruji: On The Principles of Astronomy, New Haven, Yale, 1971 .

16. For a brief review of the Ptolemaic System, see O. Neugebauer, The Exact Sciences in Antiquity, Providence, Brown University Press, 1957, p. 191-207. For a much more detailed analysis of this system, see ID., A History of Ancient Mathematical Astronomy, New York, Springer, 1975, p. 21-256.

17. See E. S. KENNEDY, art. cit. supra n. 2, p. 367, and Figure 2. 


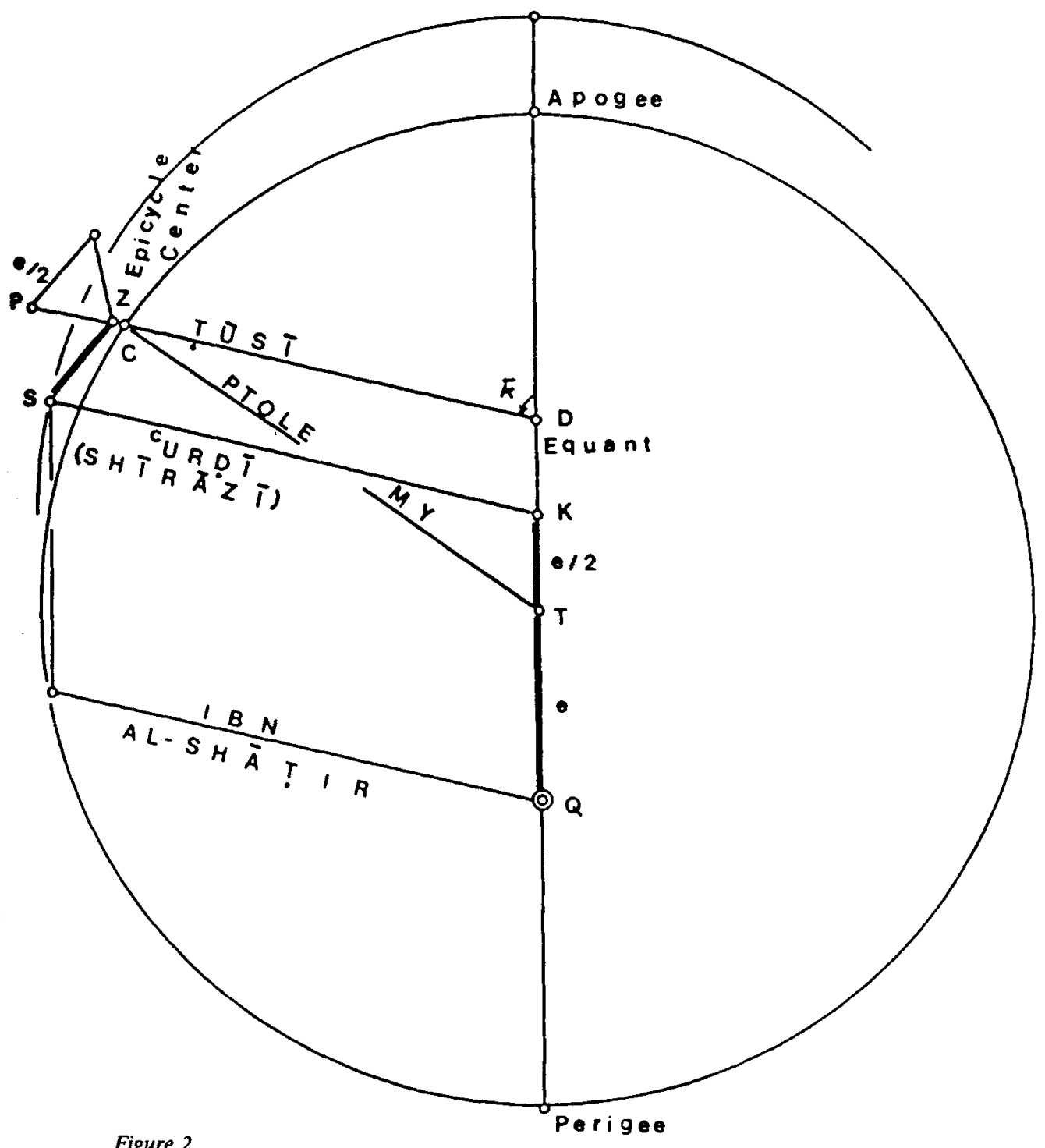

Figure 2

A summary of the models proposed by "Urdi, Tüsi, and Ibn al-Shätir, all superimposed over that of Ptolemy. Note that they all produce the motion of point $Z$, the center of the epicycle, as being uniform around point $D$, the equant. Note also that point $Z$ is very close to point $C$, Ptolemy's center of the epicycle, with a difference exaggerated simply to state that they are not identical. The earlier version of this diagram, which was published by E. S. KENNEDY, Isis, 57, 1966, p. 367, had the vector $K S$ ascribed to Qutb al-Din al-Shirazi, and that was later shown to have been invented by "Urdi some forty years earlier. 
In all of the works of these astronomers, we note that the Ptolemaic observational requirements could still be maintained. At the same time, however, the motion of the planets could then be described in mathematical models that were consistent with the physical bodies, which they were supposed to represent. Most of the recent research in Arabic Planetary theories have been devoted to the works of these astronomers, designated in Kennedy's diagram. And most of the important results have been reported in the same publications quoted so far, with the exception of the results established by the present author, specifically referring to the works of ${ }^{\mathrm{C} U r d i i ~}{ }^{18}$, and the work of a student of Ulugh Beg (c. 1450) who thus far remains unknown ${ }^{19}$.

\section{THE MARAGHA SCHOOL AND COPERNICUS}

Beginning with an article written by Victor Roberts (Isis, 1957), and several others that have followed since then ${ }^{20}$, our understanding of the rôle of Arabic astronomy has changed drastically. In 1957, Roberts showed that the lunar model of Ibn al-Shătirir (d. 1375) was essentially identical to that of Copernicus (1473-1543), thus raising the specter of indebtedness and transmission. Since then there has been a series of articles dealing with this possible link between the works of Copernicus and what came to be known as the works of the "Maragha School " 21. The last work to deal with Copernican astronomy, for example, concluded

18. See G. SAliba, "The Original Source of Qüț al-Dïn al-Shìrazìs Planetary Model ", Journal for the History of Arabic Science, 3, 1979, p. 3-18.

19. See ID., " Arabic Astronomy and the Critique of Ptolemy ", delivered at the Wellcome Institute, Dec. 14, 1984 (forthcoming).

20. Now conveniently gathered in several places, namely, in Edward S. KENNEDY, Imad GHANEm, The Life and Works of Ibn Al-Shätir, Aleppo, Aleppo University, 1976 ; E. S. KenNedy et al., Studies in the Islamic Exact Sciences, Beirut, American University of Beirut, 1983, p. 50-107. Add to that the works listed in Noel M. SwERDLow, Otto NEUGEBAUER, Mathematical Astronomy in Copernicus's De Revolutionibus, New York, Springer, 1984, p. 46, n. 7, and the most recent work of the present author, "Arabic Astronomy and Copernicus ", Zeitschrift für Geschichte der Arabisch-Islamischen Wissenschaft, vol. 1, 1985, p. 225-229.

21. See, for example, the works of E. S. Kennedy, F. Abbud, V. Roberts, now gathered in E. S. KENNEDY et al, Studies, op. cit. supra, p. 50-107 ; N. M. SwERDLow, « The Derivation and First Draft of Copernicus's Planetary Theory : A Translation of the Commentariolus with Commentary », Proceedings of the American Philosophical Society, 117, 1973, p. 423-512 ; Willy HarTner, « Nāsìr al-Dīn al-Tūsi’s Lunar Theory », Physis, 11, 1969, p. 287-304 ; ID., « Ptolemy, Azarquiel, Ibn al-Shātir, and Copernicus's Mercury Models : An Accuracy Test ", Archives internationales d'histoire des sciences, 24, 1974, p. $5-25$; G. SAlibA, art. cit. supra n. 18 ; ID., « The First Non-Ptolemaic Astronomy at the Maragha School », Isis, 70, 1979, p. $571-576$; ID., art. cit. supra n. 13 ; ID., art. cit. supra n. 19. 
by saying : « The question therefore is not whether, but when, where, and in what form he [i.e. Copernicus] learned of Marāgha theory "; and : « In a very real sense, Copernicus can be looked upon as, if not the last, surely the most noted follower of the "Marāgha School" "22.

Such, briefly, are the results reached thus far. Namely, there seems to be a dramatic similarity between the technical results reached by Copernicus, and those reached by the Maragha astronomers some two to three

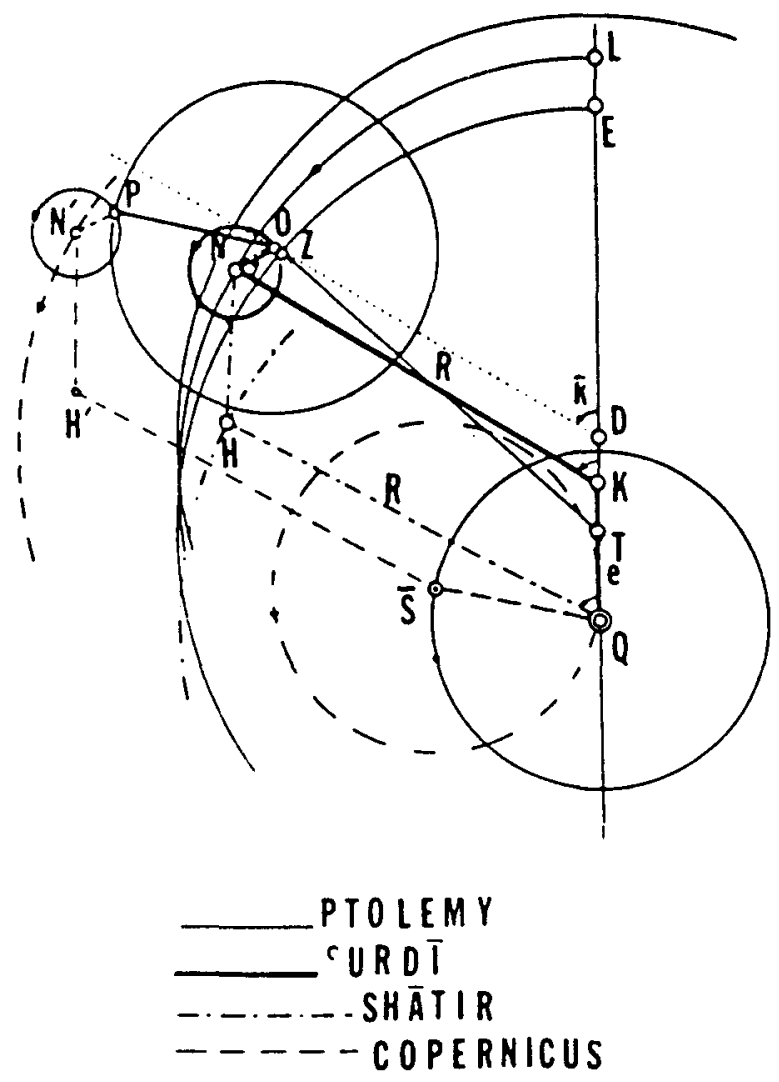

\section{Figure 3}

The four models superimposed here give the same position for planet $P$ along equal and parallel vectors. The feature of dividing the Ptolemaic eccentricity $e=D T=T Q$ at point $K$ was first proposed by "Urdi, as far as we can now tell, and was obviously used by Copernicus as vector $N P$.

22. See N. M. Swerdlow, O. Neugebauer, op. cit. supra n. 20, p. 47, 295. 
centuries earlier. The only distinction, of course, is the heliocentric theory of Copernicus, versus the geocentric one of the Maragha astronomers. But, mathematically speaking, and to put it in modern terminology, this reversal of the direction of the vector that connects the earth to the sun was so well known to Copernicus as to have been of no real mathematical significance. The realization that Copernicus's models are identical with those of the earlier Maragha astronomers, and the relationship of all these models to that of Ptolemy was illustrated by the present author in a separate article ${ }^{23}$, where it was shown that for an observer on the earth $Q$, all these projected models of Ptolemy, 'Urdị, Ibn al-Shațir, and Copernicus predicted the same position for the planet at point $P$. Note also that the adoption of the heliocentric theory, merely translates all positions into new ones along equal and parallel lines in the same direction (see Fig. 3).

\section{CONCLUSION}

In contrast to the results reached in the nineteenth century, modern research has shown that even Copernican astronomy cannot be very well understood, on the mathematical and technical levels, without a careful study of the achievements of the earlier Maragha astronomers. In another place, I have argued that these developments in Arabic astronomy can be viewed as a continuous tradition only among Arabic-writing astronomers, and not among Copernicus's predecessors ${ }^{24}$. But the real revolution in the work of the "Maragha School " astronomers lies in the philosophical dimension that was equal in impcrtance to the mathematical and astronomical dimensions if not more so, and which was in the realization that astronomy ought to describe the behaviour of physical bodies in mathematical language, and should not remain a mathematical hypothesis, which would only save the phenomena. Most importantly, this tradition, which was not fully appreciated by de Vaux, Nau and Dreyer, did indeed face the realization that the Aristotelian division of motion in the universe as being only circular or linear was not altogether true, for one could very well produce linear motion by applying circular motion only, as in the case of the "Túsi Couple " that was mentioned above.

23. See G. SAliBA, "Arabic Astronomy and Copernicus", art. cit. supra n. 20, p. 215-229, esp. p. 228.

24. Ibid. 
To recast the chronological periodization of Islamic astronomy, one would have to expand the stages of original production to include the span from the ninth to the fifteenth century. This period had several peaks of various heights ; the most important was the one that took place during the thirteenth and the fourteenth centuries, and which we have described as the Maragha Revolution.

Within the general scope of the history of astronomy, the Maragha Revolution is on the one hand a natural climax to the activities that took place between the ninth and the twelfth century, but, on the other hand, an essential link to Copernican astronomy without which Copernican astronomy will be hard to explain.

George SALIBA, Columbia University. 